\title{
In vitro antimicrobial and antioxidant activities of the essential oil of Craniotome furcata
}

\section{R. K. Joshi}

Regional Medical Research Center, Indian Council of Medical Research, Nehru Nagar, Belgaum-590 010 (Karnataka), INDIA

E-mail: joshirk_natprod@yahoo.com

\begin{abstract}
The aim of present study was, to investigate the essential oil of Craniotome furcata for its antimicrobial and antioxidant activities. The essential oil was obtained by steam distillation of the flowering aerial parts of $C$. furcata. The oil was tested for its antimicrobial activity in vitro against four Gram-positive, four Gram-negative bacteria and three fungi, by using disk diffusion and tube dilution methods. The antioxidant potential of the essential oil was investigated by two different models DPPH free radical and ABTS free radical cation scavenging. The essential oil was effective against all the tested microorganisms, with minimum inhibitory concentrations (MICs) ranged from $4.11 \pm 1.44$ to $0.30 \pm 0.10 \mathrm{mg} / \mathrm{ml}$. The oil showed antioxidant activity in DPPH free radical and ABTS free radical cation scavenging model. The results of this study revealed that the essential oil of $C$. furcata possesses antimicrobial and antioxidant activities.
\end{abstract}

Keywords: Craniotome furcata, Antimicrobial activity, MIC, Antioxidant activity, DPPH, ABTS

\section{INTRODUCTION}

Various medicinal plants have been used for years in day to day life to treat diseases all over the world. The use of traditional medicine and medicinal plants in developing countries, to meet some of their primary health care needs, has been widely documented (WHO, 2007). Several essential oils and their isolates have been found to exhibit strong antibacterial and antifungal activities. The essential oils are supposed to interfere with intermediary metabolism of microorganisms by changing the rate of an enzyme reaction influencing nutrient uptake from the medium affecting enzyme synthesis at nuclear or ribosomal level or changing membrane structures and kill the microorganisms (Delaquis, et al., 2002; Burt and Reinders, 2003). Plants have an almost limitless ability to synthesize aromatic substances, most of which are phenols or their oxygen-substituted derivatives (Geissman, 1963). These compounds protect the plant from microbial infection and deterioration (Cowan, 1999). Some of these phytochemicals can significantly reduce the risk of cancer due to polyphenol antioxidants and anti-inflammatory effects. Some preclinical studies suggested that phytochemicals can prevent colorectal cancer and other cancers (Michaud, et al., 2000; Greenberg, et al., 1994; Birt, et al., 2001). Craniotome furcata Link. O. Kuntze belongs to family Lamiaceae, the only species of the genus Craniotome, is widely distributed in temperate areas from Simla to Bhutan at a height of 1500-2300 m (Gupta, 1968). The phytochemicals present in C. furcata are cranioside A and B, mussaeniside, ningpogenin (Yue, et al., 2001) triterpene saponins, craniosaponin A and buddlejasaponins Ia and I (Fan, et al., 2002) from the ethyl acetate and n-butanol extracts respectively, while germacrene $\mathrm{D}$, germacrene D-4-ol, epiá-cadinol and 10-epi-ã-eudesmol have been reported as the main constituents of the essential oil of flowering aerial parts of this herb (Joshi and Pande, 2008). The leaves of $C$. furcata have been traditionally used for treatment of cuts and wounds (Manandhar, 1992). The present study was carried out to evaluate the antimicrobial effects and antioxidant potential of the essential oil of $C$. furcata. To the best of my knowledge, this is the first report on the antimicrobial and antioxidant activities of the essential oil of flowering aerial parts of this plant.

\section{MATERIALS AND METHODS}

Test material: The plant was collected from Nainital, India. The botanical identification was done at Botany Department, Kumaun University, Nainital, which was further confirmed by the Forest Research Institute, Dehradun, India (herbarium specimen No-34806).

Extraction of essential oil: Fresh flowering aerial parts $(1 \mathrm{~kg})$ of $C$. furcata were steam distilled using copper still fitted with spiral glass condensers for 3 hours and water distillate was extracted with n-hexane and dichloromethane. The organic phase was dried over anhydrous sodium sulphate. The solvent was removed by distillation using a thin film rotary vacuum evaporator 
at $25^{\circ}-30^{\circ} \mathrm{C}$. The yield of essential oil was $0.25 \%(\mathrm{v} / \mathrm{w})$. Composition of essential oil: The compounds studied in this assay were reported as 3 -octanone $(0.2 \%)$, ä-elemene $(0.6 \%)$, longicyclene $(3.0 \%)$, â-cubebene $(2.8 \%)$, âcaryophyllene (1.6\%), germacrene D (49.2\%), epi-cubebol (0.6\%), á-muurolene (1.8\%), trans-â-guaiene $(1.9 \%)$, germacrene A (3.2\%), cubebol (2.1\%), ä-cadinene (1.7\%), selina-3,7(11)-diene $(1.9 \%)$, germacrene B $(0.3 \%)$, germacrene D-4-ol (8.8\%), â-biotol (0.4\%), 10-epi-ãeudesmol (4.2\%), epi-á-cadinol (5.9\%), á-cadinol (2.3\%), khusinol (1.4\%) and oplopanone (1.5\%) from the essential oil of flowering aerial parts of C. furcata (Joshi and Pande, 2008).

\section{Antimicrobial activity:}

Microbial strains: Bacillus subtilis (NCIM 2063), Micrococcus flavus (NCIM 2379), Staphylococcus aureus (NCIM 2079), Staphylococcus faecalis (NCIM 2080) (Gram-positive bacteria), Escherichia coli (NCIM 2574), Klebsiella pneumoniae (NCIM 2957), Pseudomonas aeruginosa (NCIM 5029), Salmonella typhimurium (NCIM 2501) (Gram-negative bacteria) and Aspergillus niger (NCIM 620), Aspergillus fumigatus (NCIM 902) and Penicillium chrysogenum (NCIM 733) (Fungi) were obtained from the National Collection of Industrial Microorganisms (NCIM), National Chemical Laboratory, Pune, India.

Preparation of test sample: The essential oil was dissolved in $10 \%$ dimethyl sulfoxide (DMSO) which is reported to be non toxic to microorganisms at this percentage (Pujol et al., 1990) with Tween $80(1.0 \% \mathrm{v} / \mathrm{v}$ for easy diffusion) to a concentration range 3.0 to 0.005 $\mathrm{mg} / \mathrm{ml}$ for bacteria and 5.0 to $0.009 \mathrm{mg} / \mathrm{ml}$ for fungi. Negative controls were prepared using discs impregnated with $10 \%$ aqueous DMSO with Tween $80(1.0 \% \mathrm{v} / \mathrm{v})$ as solvent control and virgin control (blank control). Streptomycin (Nicholas Piramal India Limited, Gujarat, India) and fluconazole (Shwarde Pharmaceuticals (I) Pvt. Ltd., Goa, India) were used as positive reference standards for bacterial and fungal strains, respectively.

Preparation of inoculums: The inocula of microbial strains were prepared from 18 hours old culture and suspensions were adjusted to $0.5 \mathrm{McF}$ arland standard turbidity $\left(\sim 10^{4}\right.$ for bacteria and $\sim 10^{3}$ for fungi colony forming unit (CFU) per milliliter (McFarland, 1987).

Disk diffusion assay: Petri plates were prepared by pouring $20 \mathrm{ml}$ of nutrient agar (NA) (HI MEDIA, India) for bacterial strains and potato dextrose agar (PDA) (HI MEDIA, India) for fungal strains and allowed to solidify for half an hour. The inoculum $(0.05 \mathrm{ml})$ was spread on the top of the solidified media and allowed to dry for 10 $\mathrm{min}$. The sterile discs ( $6 \mathrm{~mm}$ diameter) were impregnated with $20 \mu \mathrm{l}$ of different concentrations (3.0 to $0.005 \mathrm{mg} / \mathrm{ml}$ for bacteria and 5.0 to $0.009 \mathrm{mg} / \mathrm{ml}$ for fungi) of essential oil. The plates were left for $30 \mathrm{~min}$ at room temperature to allow the diffusion of essential oil. The plates were then incubated for $24 \mathrm{~h}$ and $48 \mathrm{~h}$ at $37^{\circ} \mathrm{C}$ for bacteria and fungi, respectively. The diameters of inhibition zones were measured in milliliters (Joshi et al., 2009). Assay was carried out in duplicate and mean values are reported (Tables 1 and 2).

Tube dilution assay (minimum inhibitory concentration): The minimum inhibitory concentration (MIC) was

Table 1. Antibacterial activity of the essential oil of Craniotome furcata.

\begin{tabular}{|c|c|c|c|c|c|c|c|}
\hline \multirow[t]{2}{*}{ Microbial strains } & \multicolumn{4}{|c|}{$\begin{array}{l}\text { Essential oil (mg/ml) (Zone } \\
\text { of inhibition in } \mathbf{~ m m})\end{array}$} & \multirow{2}{*}{$\begin{array}{c}\begin{array}{c}\mathbf{R A}^{\mathbf{a}} \\
(\mathbf{m g} / \mathbf{m l})\end{array} \\
0.1\end{array}$} & \multicolumn{2}{|c|}{ Minimum inhibitory concentration (MIC) } \\
\hline & 3.0 & 1.5 & 0.75 & 0.37 & & Essential oil (mg/ml) & $\mathbf{R A}(\mathbf{m g} / \mathbf{m l})$ \\
\hline \multicolumn{8}{|l|}{ Gram-positive } \\
\hline Bacillus subtilis & 13 & 12 & 11 & - & 18 & $0.62 \pm 0.21$ & $0.003 \pm 0.001$ \\
\hline Micrococcus flavus & 12 & 11 & 10 & 8 & 13 & $0.62 \pm 0.21$ & $0.002 \pm 0.001$ \\
\hline Staphylococcus aureus & 14 & 13 & 11 & 10 & 15 & $0.30 \pm 0.10$ & $0.003 \pm 0.001$ \\
\hline Staphylococcus faecalis & 14 & 12 & 11 & 9 & 20 & $0.49 \pm 0.21$ & $0.002 \pm 0.001$ \\
\hline \multicolumn{8}{|l|}{ Gram-negative } \\
\hline Escherichia coli & 14 & 12 & 9 & - & 16 & $0.62 \pm 0.21$ & $0.002 \pm 0.001$ \\
\hline Klebsiella pneumonia & 13 & 12 & 10 & - & 20 & $1.0 \pm 0.43$ & $0.002 \pm 0.001$ \\
\hline Pseudomonas aeruginosa & 13 & 12 & 10 & 8 & 13 & $0.43 \pm 0.29$ & $0.003 \pm 0.001$ \\
\hline Salmonella typhimurium & 12 & 11 & 9 & - & 14 & $0.87 \pm 0.57$ & $0.003 \pm 0.001$ \\
\hline
\end{tabular}

${ }^{a} \mathrm{RA}=$ Reference antibiotic (Streptozotocin); MIC values are mean \pm SD of three experiments in triplicate. 
Table 2. Antifungal activity of the essential oil of Craniotome furcata.

\begin{tabular}{|c|c|c|c|c|c|c|c|}
\hline \multirow[t]{2}{*}{ Microbial strains } & \multicolumn{4}{|c|}{$\begin{array}{c}\text { Essential oil (mg/ml) (Zone of } \\
\text { inhibition in } \mathbf{~ m m})\end{array}$} & \multirow{2}{*}{$\begin{array}{c}\begin{array}{c}\mathbf{R A}^{\mathrm{a}} \\
(\mathrm{mg} / \mathrm{ml})\end{array} \\
0.1\end{array}$} & \multicolumn{2}{|c|}{$\begin{array}{c}\text { Minimum inhibitory concentration } \\
\text { (MIC) }\end{array}$} \\
\hline & 5.0 & 2.5 & 1.2 & 0.62 & & Essential oil (mg/ml) & RA (mg/ml) \\
\hline \multicolumn{8}{|l|}{ Fungi } \\
\hline Aspergillus niger & 9 & - & - & - & 13 & $4.11 \pm 1.44$ & $0.006 \pm 0.002$ \\
\hline Aspergillus fumigatus & 8 & - & - & - & 12 & $2.91 \pm 1.90$ & $0.005 \pm 0.002$ \\
\hline Penicillium chrysogenum & 8 & - & - & - & 14 & $3.75 \pm 2.16$ & $0.006 \pm 0.002$ \\
\hline
\end{tabular}

${ }^{\mathrm{a}} \mathrm{RA}=$ Reference antibiotic (Fluconazole); MIC values are mean \pm SD of three experiments in triplicate

determined using tube-dilution technique. The essential oil was dissolved in $10 \%$ dimethyl sulfoxide (DMSO) with Tween $80(1.0 \% \mathrm{v} / \mathrm{v}$ for easy diffusion). The final concentration of essential oil was $3.0 \mathrm{mg} / \mathrm{ml}$ for bacterial strains while $5.0 \mathrm{mg} / \mathrm{ml}$ for fungal strains, respectively. Serial (two-fold) dilution was prepared from the stock solution to give concentration ranging from $3.0-0.005 \mathrm{mg} /$ $\mathrm{ml}$ of the oil for bacterial strains. The concentration range screened for fungal strains was $5.0-0.009 \mathrm{mg} / \mathrm{ml}$ of the oil. Streptomycin and fluconazole were dissolved in sterile distilled water and two-fold dilutions were prepared (1.02 $\mathrm{mg} / \mathrm{ml}$ to $0.001 \mathrm{mg} / \mathrm{ml}$ ). One $\mathrm{ml}$ of each concentration was mixed with $1.0 \mathrm{ml}$ of sterile peptone water $\left(10^{4} \mathrm{CFU} / \mathrm{ml}\right.$ for bacteria and $10^{3} \mathrm{CFU} / \mathrm{ml}$ for fungal concentration, obtained from a McFarland turbidity standard (no. 0.5). Solvent control was prepared with DMSO (10\%) with Tween $80(1.0 \% \mathrm{v} / \mathrm{v})$ and blank control was prepared by virgin media. Tubes were incubated for $24 \mathrm{~h}$ and $48 \mathrm{~h}$ at $37^{\circ} \mathrm{C}$ for bacteria and fungi, respectively. Assay was repeated in triplicate. The MIC values are expressed as mean \pm standard deviation. The lowest concentration that inhibits the visible microbial growth was determined as MIC (Murthy et al., 2006 and Kuta, 2008).

\section{Antioxidant activity:}

DPPH radical scavenging activity: The antioxidant activity of the essential oil was determined using 2, 2diphenyl-1-picrylhydrazyl (DPPH) radical according to the method of Hou et al., 2001, with slight modification. The principle of the reduction of DPPH free-radical assay is that antioxidants react with the stable DPPH free radical and convert it into 1, 1-diphenyl-2-picryl hydrazine. The ability to scavenge the stable DPPH free radical is measured by a decrease in the absorbance. The DPPH free stable radical scavenger, which was dissolved in ethanol to give a $0.05 \mathrm{mM}$ solution. Aliquots containing various concentrations $(10-100 \mu \mathrm{g})$ of antioxidant reference (ascorbic acid) in the final volume of $1.0 \mathrm{ml}$ were mixed with $1.0 \mathrm{ml}$ of ethanolic DPPH solution. The oil was tested using the same method. The ethanolic solution of DPPH $(1.0 \mathrm{ml})$ with equal amount of ethanol served as control. The reaction mixtures were incubated at $37^{\circ} \mathrm{C}$ for $20 \mathrm{~min}$ and the absorbance of reaction mixtures was recorded at $517 \mathrm{~nm}$.
ABTS radical decolourization assay: 2, 2-azinobis (3ethylbenzothiazoline-6-sulfonicacid (ABTS) diammonium salt radical cation decolourization test was performed using spectrophotometric method of Pellegrini et al., 1999. The principle of the ABTS diammonium salt cation radical decolourization assay is that the antioxidants react with ABTS resulting in the decolourization of the ABTS radical in aqueous phase. The ABTS stock reagent mixture was prepared by mixing $88 \mu \mathrm{l}$ of $140 \mathrm{mM}$ potassium persulfate $\left(\mathrm{K}_{2} \mathrm{~S}_{2} \mathrm{O}_{8}\right)$ with $5 \mathrm{ml}$ of $7 \mathrm{mM}$ of ABTS stock solution $(\mathrm{pH}$ 7.4). The working ABTS reagent was prepared by diluting the stock solution with ethanol to give an absorbance of $0.7 \pm 0.05$ at $734 \mathrm{~nm}$. Aliquots containing various concentrations (10-100 $\mu \mathrm{g}$ ) of antioxidant reference (ascorbic acid) in the final volume of $1.0 \mathrm{ml}$ were mixed with $1.0 \mathrm{ml}$ of working ABTS solution. The oil was tested using the same method. The ABTS working solution (1.0 $\mathrm{ml}$ ) with equal amount of ethanol served as control. The reaction mixtures were incubated at room temperature. The absorbance was measured at $734 \mathrm{~nm}$ after initial mixing of the reactants within 1-3 minutes.

The change in the absorbance of the reaction mixture in DPPH and ABTS assay were measured using a double beam UV-Vis spectrophotometer (ECIL) and the percent scavenging or inhibition was calculated according to the following formula.

Percent scavenging or inhibition $=($ Absorbance of control - Absorbance of test / Absorbance of control) $\mathrm{x}$ 100. All the experiments were performed three times and the values were presented as Mean \pm SEM.

\section{RESULTS AND DISCUSSION}

Antimicrobial activity: Table 1 and 2 summarizes the qualitative (diameters of inhibition zones) and quantitative results (minimum inhibitory concentrations) of the in vitro antimicrobial effect of the essential oil of C. furcata on the eleven microbial strains. The diameters of inhibitory zones recorded in millimeter. It was observed that the oil was effective against all tested microbial strains. The size of all inhibition zones were between 8 to $14 \mathrm{~mm}$. Average size of inhibition zones was around 11 $\mathrm{mm}$. The effective dilution range of essential oil was observed at $3.0-0.37 \mathrm{mg} / \mathrm{ml}$ for bacterial strains, while 5.0 
Table 3. Antioxidant potential of essential oil of DPPH and ABTS free radicals.

\begin{tabular}{lcc}
\hline Material & DPPH $^{\cdot}(\boldsymbol{\mu g} / \mathbf{m l})^{\mathbf{a}}$ & ABTS $^{+}(\boldsymbol{\mu g} / \mathbf{m l})^{\mathbf{a}}$ \\
\hline Essential oil & $30.33 \pm 0.66$ & $48.33 \pm 0.66$ \\
Ascorbic acid & $8.33 \pm 0.57$ & $7.33 \pm 0.88$ \\
\hline
\end{tabular}

Values expressed as mean $\pm \mathrm{SEM}$; ${ }^{\text {Expressed by }} \mathrm{IC}_{50}$ values $(\mu \mathrm{g} / \mathrm{ml})$.

$\mathrm{mg} / \mathrm{ml}$ of essential oil was effective against fungal strains, which were comparatively resistant than the bacterial strains. Microorganisms most susceptible at a concentration of $3.0 \mathrm{mg} / \mathrm{ml}$ of the essential oil were $S$. aureus, S. faecalis, E. coli (inhibition zones (IZ) $14 \mathrm{~mm}$ ), B. subtilis, K. pneumoniae, $P$. aeruginosa (IZ $13 \mathrm{~mm}$ ) and M. flavus and S. typhimurium (IZ 12), while $5.0 \mathrm{mg}$ / $\mathrm{ml}$ was observed with zone of inhibition $9 \mathrm{~mm}$ for $A$. niger and $8 \mathrm{~mm}$ for $A$. fumigates and $P$. chrysogenum, respectively. The MICs of the oil demonstrated good activity against tested microorganisms. The organisms like $S$. aureus was found to be most susceptible with MIC value of $0.30 \pm 0.10 \mathrm{mg} / \mathrm{ml}$, while P. aeruginosa and $S$. faecalis were found moderately susceptible with MIC values $0.43 \pm 0.29$ and $0.43 \pm 0.21 \mathrm{mg} / \mathrm{ml}$. The microorganisms $B$. subtilis, $M$. flavus and $E$. coli were less susceptible at a concentration of $0.62 \pm 0.21 \mathrm{mg} / \mathrm{ml}$. The organisms like K. pneumonia and S. typhimurium were comparatively less sensitive with a concentration of $1.0 \pm 0.43$ and $0.87 \pm 0.57 \mathrm{mg} / \mathrm{ml}$ respectively. The MIC value was found $2.91 \pm 1.90$ for $A$. fumigates while, the organisms $P$. chrysogenum and $A$. niger were comparatively less susceptible at a concentration of 3.75 \pm 2.16 and $4.16 \pm 1.44 \mathrm{mg} / \mathrm{ml}$. The essential oil was effective against bacterial strains than fungal strains.

It is interesting to point out that the microorganisms demonstrating the biggest inhibition zones by diffusion method are not always the ones that present the lowest
MIC values. In fact, the diameter of the growth inhibition zone is affected by the oil solubility and volatility (Hernandez et al., 2005). According to Wan et al., 1998, the majority of the essential oil assayed for their antibacterial properties showed a more pronounced effect against the Gram-positive bacteria. The resistance of Gram-negative bacteria to essential oil has been ascribed to their hydrophilic outer membrane which can block the peneteration of hydrophobic compounds into target cell membrane (Inouye et al., 2001).

The antimicrobial activity of the essential oil of $C$. furcata correlates with the content of germacrene D-4-ol, â-biotol, cubebol, 10-epi-ã-eudesmol, epi-á-cadinol, á-cadinol, khusinol and oplopanone reported in this oil. The phenolic compounds are among most efficient plant antimicrobial agents known to date (Nazer et al., 2005). Furthermore, a sesquiterpene hydrocarbon like germacrene D rich essential showed good antimicrobial and cytotoxicity activity. In vitro cytotoxicity activity of germacrene D was found cytotoxic against Human Hs 578T breast ductal carcinoma cells (Palazzo et al., 2009). The antimicrobial activity of the essential oil of $C$. furcata was more effective against the tested bacterial strains while comparatively resistant against tested fungal strains.

Antioxidant activity: Due to its complexity more than one test must be carried out when evaluating the antioxidant activity of pure compounds or extracts (Aruoma, 2003). In this study, two models were selected to evaluate the antioxidant potential of the essential oil of $C$. furcata. Antioxidant activities of the essential oils from aromatic plants are mainly attributed to the active compounds present in them. This can be due to the high percentage of the main constituents, but also to the presence of other constituents in small quantities or to synergy among them (Abdalla et al., 1999). The chemical complexity of the essential oil, often a mixture of dozens of compounds with different functional groups, polarity and chemical

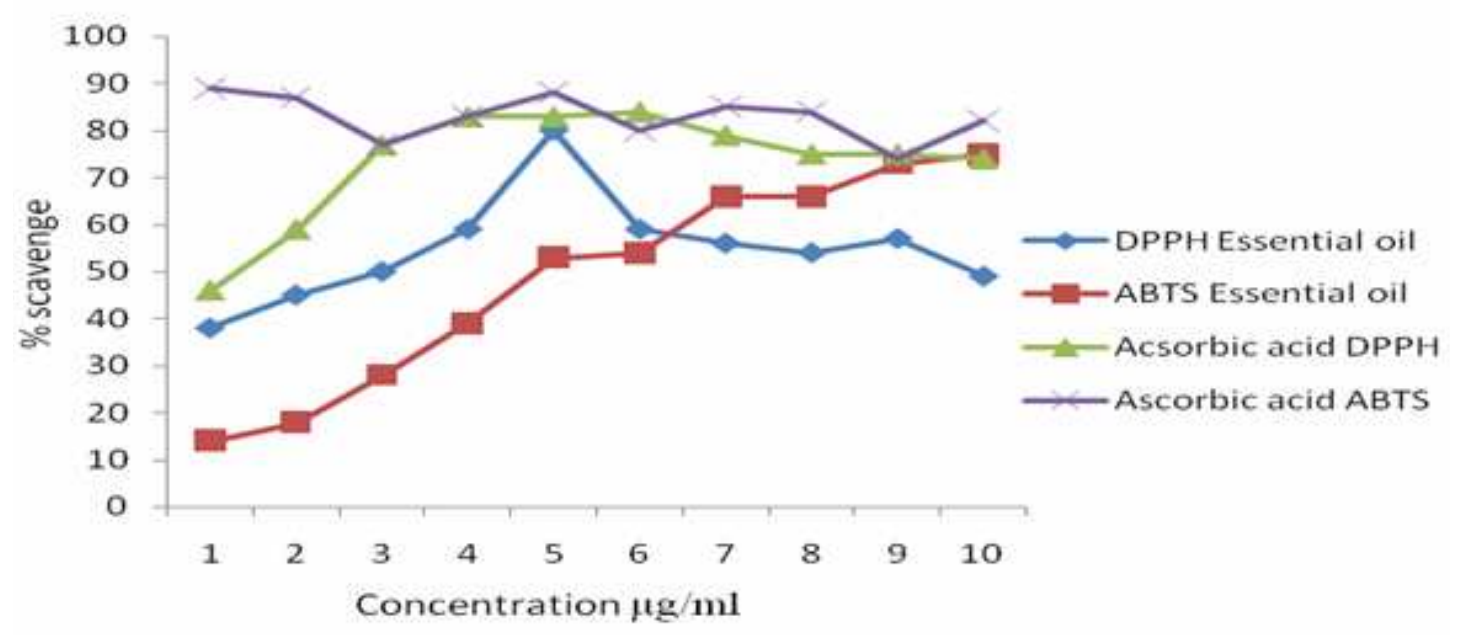

Fig. 1. Antioxidant activity of the essential oil of Craniotome furcata. 
behavior, the antioxidant activity can occur through several mechanisms. For determination of in vitro antioxidant activity of the essential oil of $C$. furcata, DPPH free radical and ABTS free radical cation scavenging models were used. DPPH and ABTS are stable free radicals that can accept an electron or hydrogen radical to become stable diamagnetic molecule. The DPPH radical is widely used as a model system to investigate the free-radical scavenging activities of several plant extracts. Fig. 1 shows the concentration of essential oil on DPPH radical and ABTS radical cation scavenging activity. The DPPH and ABTS scavenging activities were compared with standard ascorbic acid (Table 3). The essential oil scavenged the DPPH radicals in a concentration-dependent manner with the maximum scavenging activity of $80 \%$ at $50 \mu \mathrm{g} / \mathrm{ml}$ did not attained saturation with further increase in the essential oil concentration. The $\mathrm{IC}_{50}$ value was found to $30.33 \pm 0.66$ $\mu \mathrm{g} / \mathrm{ml}$. Similarly essential oil demonstrated ABTS radical scavenging activity in a concentration dependent manner with $76 \%$ at $100 \mu \mathrm{g} / \mathrm{ml}$ essential oil concentration attaining saturation with higher concentrations. The $\mathrm{IC}_{50}$ value was observed $48.33 \pm 0.66 \mu \mathrm{g} / \mathrm{ml}$. (Fig. 1). The results presented in this study revealed that the $C$. furcata essential oil possesses antioxidant capacity to scavenge free radicals, which can be ascribed the content of the phenolic compounds in this oil. In fact, various studies reported the correlation between the phenolic content and the antioxidant capacity of plant extracts (Gulcin, $e t$ al., 2004; Chun et al., 2005). Germacrene D-4-ol, 10-epi-ãeudesmol, epi-á-cadinol, á-cadinol, and khusinol were the main compounds of this oil, can be responsible for antioxidant activity, due to the presence of hydroxyl groups in their chemical structure.

\section{Conclusion}

The Lamiaceae plants have many medicinal uses especially due to their high content of essential oils. The results in this study revealed that, the essential oil of $C$. furcata has antibacterial property while the oil was less effective against the tested fungal strains. The antioxidant activity of the essential oil of $C$. furcata may be an alternative to more toxic synthetic antioxidants as additives in food, pharmaceutical and cosmetic preparations. In conclusion the essential oil of $C$. furcata has antimicrobial and antioxidant properties.

\section{ACKNOWLEDGEMENTS}

The author is grateful to Dr. S. D. Kholkute, Officer-inCharge of Regional Medical Research Centre (ICMR) for providing necessary facilities and encouragement. The author is also thankful to Mr. M. H. K. Mujawar for assistance during the experimental work and also grateful to Prof. Y. P. S. Pangtey, Botany Department, Kumaun University, Nainital for identification of plant materials.

\section{REFERENCES}

Abdalla, A.E. and Roozen, J.P. (1999). Effect of plant extracts on the oxidative stability of sunflower oil and emulsion. Food Chemistry, 64: 323-329.

Aruoma, O.I. (2003). Methodological considerations for characterizing potential antioxidant actions of bioactive components in plant foods. Mutation Research, 9: 523-524.

Birt, D.F., Hendrich, S. and Wang, W.Q. (2001). Dietary agents in cancer prevention: flavanoids and isoflavonoids. Pharmacology and Therapeutics, 90: 157-177.

Burt, S.A. and Reinders, R.D. (2003). Antibacterial activity of selected plant essential oils against Escherichia coli O157:H7. Letters in Applied Microbiology, 36: 162-167.

Chun, S.S., Vattem, D.A., Lin, Y.T. and Shetty, K. (2005). Phenolic antioxidants from clonal oregano (Origanum vulgare) with antimicrobial activity against Helicobacter pylori. Process Biochemistry, 40: 809-816.

Cowan, M.M. (1999). Plant products as antimicrobial agents. Clinical Microbiology Reviews, 12: 564-582.

Delaquis, P.J., Stanich, K., Girard, B. and Mazza G. (2002). Antimicrobial activity of individual and mixed fractions of dill, cilantro, coriander and eucalyptus essential oils. International Journal of Food Microbiology, 74: 101-109.

Fan, C.Q., Sun, H.F., Chen, S.N., Yue, J.M., Lin, Z.W. and Sun, H.D. (2002). Triterpene saponins from Craniotome furcata. Natural Product Letters, 16: 161-166.

Geissman, T.A. (1963). Flavonoid compounds, tannins, lignins and related compounds. In: Florkin M and Stotz EH (eds). Pyrrole Pigments, Isoprenoid Compounds and Phenolic Plant Constituents. New York, USA, Elsevier Press.

Greenberg, E.R., Baron, J.A. and Tosteson, T.D. (1994). A clinical trial of antioxidant vitamins to prevent colorectal cancer. New England Journal of Medicine, 331: 141-147.

Gulçin, I., Sat, I.G., Beydemir, S., Elmastas, M. and Kufrevioglu, O.I. (2004). Comparison of antioxidant activity of clove (Eugenia carphylata Thumb) buds and lavender (Lavandula stoechas L.). Food Chemistry, 87: 393-400.

Gupta, R.K. (1968). Flora Nainitalensis. New Delhi: Navyug Publication, p. 276.

Hernandez, T., Canales, M., Avila, J.G., Garcia, A.M., Martínez, A., Caballero, J., Romo de Vivar, A. and Lira, R. (2005). Composition and antibacterial activity of essential oil of Lantana achyranthifolia Desf. (Verbenaceae). Journal of Ethnopharmacology, 96: 551-554.

Hou, W.C., Chen, Y.C., Chen, H.J., Lin, Y.H., Yang, L.L. and Lee, M.H. (2001). Antioxidant activities of trypsin inhibitor, a $33 \mathrm{KDa}$ root storage protein of sweet potato (Ipomoea batatas (L.) Lam cv. Tainong 57). Journal of Agriculture and Food Chemistry, 49: 2978-2981.

Inouye, S., Yamaguchi, H. and Takizawa, T. (2001). Screening of the antibacterial effects of variety of essential oils on respiratory tract pathogens, using a modified dilution assay method. Journal of Infection Chemotherapy, 7: 251-254.

Joshi, R. K., Pande, C., Mujawar, M. H. K., and Kholkute, S. D. (2009). Chemical composition and antimicrobial activity of the essential Oil of Anaphalis nubigena var. monocephala. Natural Product Communications, 4: 993-996.

Joshi, R.K. and Pande, C. (2008). Chemical composition of the essential oil of the flowering aerial parts of Craniotome furcata. Natural Product Communications, 3: 923-924. 
Kuta, F.A. (2008). Antifungal effect of Calotropis procera stem bark on Epidermophyton flocosum and Trichophyton gypseum. African Journal of Biotechnology, 7: 2116-2118.

Manandhar, N.P. (1992). Folklore medicine of Dhading district, Nepal. Fitoterapia, 63: 163-177.

McFarland, J. (1987). Standardization of bacterial culture for the disc diffusion assay. Journal of the American Medical Association, 49: 1176-1178.

Michaud, D.S., Feskanich, D., Rimm, E.B., Colditz, G. A., Speizer, F. E., Willett, W. C. and Giovannucci, E. (2000). Intake of specific carotenoids and risk of lung cancer in two prospective U.S. cohorts. American Journal of Clinical Nutrition, 72: 990-997.

Murthy, M.M., Subramanyam, M., Giridhar, K.V. and Jetty, A. (2006). Antimicrobial activities of bharangin from Premna herbaceae Roxb. and bharangin monoacetate. Journal of Ethnopharmacology, 104: 290-292.

Nazer, A.I., Kobilinsky, A., Tholozan, J.L. and DuboisBrissonnet, F. (2005). Combinations of food antimicrobials at low levels to inhibit the growth of Salmonella $s v$. Typhimurium: a synergistic effect. Food Microbiology, 22: 391-398.
Palazzo, M.C., Agius, B.R., Wright, B.S., Haber, W. A., Moriarity, D.M. and Setzer, W.N. (2009). Chemical compositions and cytotoxic activities of leaf essential oils of four Lauraceae tree species from Monteverde, Costa Rica. Records of Natural Products, 3: 32-37.

Pellegrini, N., Re, R., Yang, M. and Rice-Evans, C. (1999). Screening of dietary carotenoids and carotenoid-rich fruit extracts for antioxidant activities applying 2,2' azinobis (3ethyenebenzothiazoline-6-sulfonic acid) radical cation decolourization assay. Methods Enzymol, 299: 379-389.

Pujol, V., Seux, V. and Villard, J. (1990). Recherche de substances antifongiques secretees par les champignons superieurs en culture. Annales Pharmaceutiques Francaises, 48: $17-22$.

Wan, J., Wilcock, A. and Coventry, M. J. (1998). The effect of essential oils of basil on the growth of Aeromonas hydrophila and Pseudomonas fluorescens. Applied Microbiology, 84: $152-158$.

WHO, (2007). http://www.who.int/mediacentre/factsheets/ fs 134/en/.

Yue, J.M., Chen, S.N., Yang, S.P., Fan, C.Q., Lin, Z.W. and Sun, H.D. (2001). Chemical components from Craniotome furcata. Zhiwu Xuebao, 43: 1199-1201. 